\title{
The Bulgarian Constitutional Order, Supranational Constitutionalism and European Governance
}

\author{
Evgeni Tanchev and Martin Belov
}

\begin{abstract}
Bulgaria's 1991 Constitution is regarded as a 'reactive constitution', reflecting the transition from totalitarianism to democracy. It aims to introduce a genuinely new political model based on different concepts about the individual and the state, with legally defensible human rights, and makes the Constitution a substantial part of enforceable law. Whilst there are issues in practice, including the need for the EU post-accession monitoring process, the approach to constitutional review emerges as stringent. During the period 1991-2006, in the 158 challenges against Acts of Parliament, the Acts were declared to be partially or fully unconstitutional in 79 cases, often on rule of law grounds. With regard to EU integration, the Constitution has been amended extensively. The report considers such amendments to be important, as otherwise the Constitution would lose its regulative force for citizens. The report identifies the paradox that while minor domestic changes need to pass strict constitutional amendment hurdles, the transfer of constitutional powers to the EU can be done by the easier procedure for ratification of treaties. There has been no significant debate in Bulgaria regarding EU measures such as the European Arrest Warrant. The slogan 'Brussels wills it!' has functioned as a key explanatory strategy. Nevertheless, the report recalls that under the Bulgarian Constitution a reduction of rights protection is legitimate only on limited grounds, and finds that higher integration goals and teleological excuses based on efficiency arguments could not justify a reduction of the standard of protection.
\end{abstract}

Evgeni Tanchev is Advocate General of the Court of Justice of the European Union; at the time of writing Professor of Constitutional Law, New Bulgarian University, Sofia, and Vice-President, Venice Commission of the Council of Europe. e-mail: etanchev@yahoo.com.

Martin Belov is Associate Professor of Constitutional and Comparative Constitutional Law, Faculty of Law, University of Sofia 'St. Kliment Ohridski'. e-mail: martinbelov@yahoo.com.

All websites accessed 31 October 2015. Text submitted 20 December 2014.

E. Tanchev (ه)

New Bulgarian University, Sofia, Bulgaria

e-mail: etanchev@yahoo.com

M. Belov

University of Sofia 'St. Kliment Ohridski', Sofia, Bulgaria

e-mail: martinbelov@yahoo.com

(C) The Author(s) 2019

A. Albi and S. Bardutzky (eds.), National Constitutions in European

and Global Governance: Democracy, Rights, the Rule of Law,

https://doi.org/10.1007/978-94-6265-273-6_23 
Keywords The Constitution of Bulgaria - Constitutional amendments regarding EU and international co-operation - The Bulgarian Constitutional Court Constitutional review statistics - Fundamental rights and the rule of law European Arrest Warrant - Data Retention Directive Limitation of rights European constitutionalism

\section{Constitutional Amendments Regarding EU Membership}

\subsection{Constitutional Culture}

1.1.1 The 1991 Bulgarian Constitution was adopted at the beginning of the transition from totalitarianism to democracy. It is a reactive constitution ${ }^{1}$ that marks a radical legal and political break-up from both of the previous stages of Bulgarian constitutional development - the period of constitutional monarchy (1879-1947) and the period of a Soviet-type people's democracy (1947-1991). Hence, it aims at introducing a genuinely new political model based on different concepts about the individual and the state. This new legal model lays down the foundations of legally defensible human rights and of the powers of state institutions, and makes the Constitution a substantial part of the valid and enforceable law. This can be regarded as a profound break from the old regime due to the fact that the previous 1947 and 1971 Constitutions were regarded more as political acts and declarations of intent for constitutional engineering ${ }^{2}$ rather than as directly applicable legal acts.

The 1991 Bulgarian Constitution is both a cornerstone of the political system and the supreme source of law. The political and legal aspects of its nature are balanced. As a result, the current Bulgarian Constitution contains both legal principles, values and aims that serve as a channel of influence for the meta-legal normative systems, ${ }^{3}$ as well as detailed legal provisions that are enforceable in the courts. $^{4}$

\footnotetext{
${ }^{1}$ Bogdanor 1988, pp. 7-9.

${ }^{2}$ For the constitutional engineering concept, see Sartori 1994.

${ }^{3}$ The constitutional principles are cores of crystallisation around which the value system and the philosophy of the constitution are being developed. At the same time they act as channels for the introduction of meta-legal (philosophical, ethical, religious, economic, etc.) concepts and values into constitutional law. The reason is that they may serve as incentives for value-based legal argumentation by the courts as well as for legislation founded on constitutionally enshrined meta-legal categories. See Belov 2010, p. 193.

${ }^{4}$ However, according to recent surveys, a substantial percentage of Bulgarian magistrates (judges and state prosecutors) consider the Constitution as meta-law that is above but also behind and away from the 'real' law - the parliamentary statutes and normative acts of the executive. Only $41.7 \%$ of the magistrates declare that they regularly apply the Constitution directly in pending cases whereas $40.2 \%$ of them would apply the Constitution if this were consistent judicial practice; $2.8 \%$ try to avoid its direct application and 5\% never apply it directly. See Belov 2012, pp. 29-45.
} 
The current Bulgarian legal and constitutional culture is a mixture of continental European, post-Soviet and, more recently, US influences. More precisely, moderate paternalistic views with regard to the role of the state and its relations with the citizens are intertwined with more recent liberal and even libertarian influences. This mixture enriches the Bulgarian constitutional culture, but also makes it rather eclectic. Hence, the non-cohesive amalgamation of quite different political concepts in the ideal constitution is one of the explanations for the disfunctionality of the 1991 Constitution in political practice.

1.1.2 The 1991 Constitution combines the raison d'état (state oriented) dimension with the human rights and societal dimension. It tries to ascertain the value of the state's authority based on the principle of the people's sovereignty. The organisation of the state as an efficient machinery for social management is one of its key goals. The current Bulgarian Constitution establishes the normative background for the existence of all key state institutions as well as for the local self-government bodies.

The 1991 Constitution devotes special attention to the rule of law, the protection of human rights and the restriction of the activity of state institutions to their constitutionally established spheres of competence. Moreover, it contains extensive provisions on human rights and fundamental freedoms as well as the means for their protection. Thus, the constitutional goals and values of the authority, efficiency and responsiveness of the government on the one hand, and of limited and responsible government on the other hand, are balanced by the 1991 Constitution.

\subsection{The Amendments of the 1991 Consttution in Relation to the European Union}

1.2.1 The 1991 Constitution of Bulgaria has been amended four times: in 2003, 2005, 2006 and 2007. The constitutional amendments were introduced in the context of, and with view to, the membership of Bulgaria in the EU, although not all of them directly concern EU matters.

Three groups of constitutional amendments can be identified. The first group concerns amendments which are directly related to the EU. The EU related constitutional amendments concern the integration clause (Art. 4 para. 3 ), ${ }^{5}$ the right of EU citizens and companies as well as of the citizens and companies of states with which Bulgaria has a special treaty on acquiring property over land (Art. 22 paras.

\footnotetext{
${ }^{5}$ Article 4 para. 3, 'The Republic of Bulgaria shall participate in the construction and the development of the European Union.' All quotes are taken from the English translation of the Constitution of the Republic of Bulgaria available on the website of the National Assembly of the Republic of Bulgaria at http://www.parliament.bg/en/const, unless otherwise noted.
} 
1 and 2), ${ }^{6}$ the compulsory parliamentary ratification by a two-thirds majority of the Members of Parliament (MPs) of treaties that transfer competences stemming from the Bulgarian Constitution to the EU (Art. 85 para. 1 p. 9 and para. 2) ${ }^{7}$ and the competences of the National Assembly for information and control over the activity of the Government on EU matters and on the EU level (Art. 105 paras. 3 and 4). ${ }^{8}$ Last but not least, the Constitution was amended to provide electoral rights for EU citizens in EU Parliament and local elections. ${ }^{9}$

In the context of EU-related amendments, one should also mention Art. 25 para. 4 , according to which:

No Bulgarian citizen may be surrendered to another State or to an international tribunal for the purposes of criminal prosecution, unless the opposite is provided for by international treaty that has been ratified, published and entered into force for the Republic of Bulgaria.

This provision concerns both extraditions to the International Criminal Court in The Hague and the European Arrest Warrant (EAW).

The second group encompasses amendments which directly aim at reforming the judiciary. However, many of them were actually introduced in the context of Bulgaria's EU accession negotiations. Thus they are to some extent the result of the desire to satisfy the expectations of EU partners for improvement of the rule of law in Bulgaria. This second group of constitutional amendments include: the clarification of the functions of the state prosecutors' office; the establishment of a constitutional ground for the conduct of criminal investigations not only by state investigators who are magistrates but also by police officers; improvement of the system for the irremovability of magistrates and the replacement of their absolute immunity with functional immunity; the introduction of a mandate for the administrative heads of the courts, and state prosecutors' and state investigators' offices; the introduction of annual reports of the Supreme Court of Cassation, the Supreme Administrative Court and the Prosecutor General on the application of the law and on the activity of the courts, the prosecution office and the investigating bodies, which are submitted to the National Assembly by the Supreme Judicial Council; the constitutional provision of conditions for expiration of the mandate of

\footnotetext{
${ }^{6}$ Article 22 para. 1, 'Foreigners and foreign legal entities may acquire property over land under the conditions ensuing from Bulgaria's accession to the European Union, or by virtue of an international treaty that has been ratified, promulgated and entered into force for the Republic of Bulgaria, as well as through inheritance by operation of the law.' Article 22 para. 2 'The law ratifying the international treaty referred to in para. 1 shall be adopted by a majority of two thirds of all members of the Parliament.'

${ }^{7}$ Article 85 para. 1 point 9, 'The National Assembly shall ratify or denounce by law all international treaties which ... confer to the European Union powers ensuing from this Constitution.' Article 85 para. 2, 'The law ratifying the international treaty referred to in para. 1, item 9 shall be adopted by a majority of two-thirds of all members of the Parliament.'

${ }^{8}$ The constitutional provisions regarding parliamentary control over the government on EU matters will be provided later in Sect. 1.4.

${ }^{9}$ Article 42 para. 3, 'The elections for Members of the European Parliament and the participation of European Union citizens in the elections for local authorities shall be regulated by law.'
} 
elected members of the Supreme Judicial Council and of the key competences of the Minister of Justice; and the establishment of an Inspectorate subordinated to the Supreme Judicial Council.

The third group of constitutional amendments is not thematically coherent and aims at improving different aspects of the Constitution. These include constitutional provisions for the national Ombudsman, which until 2006 was provided for only by an Act of Parliament, the competence of the Ombudsman to petition the Constitutional Court to declare unconstitutional any law which infringes human rights and freedoms, the provision of a separate budget for the National Assembly as well as a quorum for adoption of its Acts, some adjustments of the constitutional texts on the military forces reflecting the abolition of compulsory military service, the right of MPs to renounce immunity in writing and grant permission for the initiation of criminal proceedings against them, and the introduction of the competence of municipal councils to determine the rates of local taxes under conditions, by a procedure and within the framework established by law.

As for the timeline, the Bulgarian Constitution was amended after the initial period of transition to democracy and before accession to the EU. The fact that so many amendments were made in a very short period of time (from 2003 until 2007) could be interpreted as an indication of a lack of consistency in the ideas of the Members of Parliament and of their inability to generate sufficient political will for reforms. However, this was also a result of the wish of the constitutional legislator to use a step-by-step approach and to adjust the Bulgarian Constitution to the demands of EU law through the most cautious and non-radical manner.

That is why the method of constitutional gradualism ${ }^{10}$ has been used in the course of the EU adaptation of the 1991 Constitution. Although there were four waves of constitutional amendments that concerned a great number of constitutional provisions, almost all of them were incremental because they tackled matters of secondary importance. A typical characteristic of constitutional gradualism is a step-by-step adjustment of the written constitution to the demands of social life through testing the political, economic and social effects produced by constitutional reform. Overall, the reform of the 1991 Bulgarian Constitution was wide in range but generally did not touch upon the key principles and cornerstones of the institutional design.

The only radical and fundamental amendment that was introduced was the EU integration clause, which provides as follows: 'The Republic of Bulgaria shall participate in the construction and the development of the EU'. Despite its modest, declarative and even decorative wording, this provision represented a profound structural change in Bulgarian constitutional statehood. This is due to the fact that it serves as a key element of the constitutional foundations for the primacy of EU law and for the addition of a new supranational layer of institutions above the national constitutional design. However, the change was not considered so far-reaching as to require the convening of the special constituent body, the Grand National

${ }^{10}$ Tanchev and Belov 2008, pp. 3-19. 
Assembly, which is envisaged for amendments that concern the form of territorial distribution of power (see below). This was confirmed by the Constitutional Court in Decision No. 3 of $2004^{11}$ and, consequently, the amendment was adopted by the National Assembly (Parliament). The logic of this Constitutional Court decision is that the EU is not a federation. The Court further clarified that the form of the territorial distribution of power concerns only the internal aspect of the vertical separation of powers and not the external aspect which relates to participation in supranational organisations. There are a multitude of new supranational forms of distribution of public power, which are not limited to the federalist option. In the reasoning of the decision, the Court stated that

\begin{abstract}
the EU is neither a federation nor any other form of territorial structure of statehood. EU membership does not concern the territorial integrity of the state as one of the elements of the form of the territorial distribution of power ... . The EU has no ambition to play the role of a federal state. Moreover, the Constitution for Europe cannot be interpreted literally as a constitution in the known legal sense. Consequently, all comparisons with the established legal order of a state are inadmissible at least in the context of an interpretative decision of the Constitutional Court.
\end{abstract}

On the other hand, despite the Court's ruling, it is obvious that the EU constitutes a new level in the hierarchy of public power with regard to the vertical polycentrism of power centres and institutional schemes. Moreover, there is an increasing trend to not limit public power to the notion and concept of state power. Hence, it could also be argued that the summoning of the Grand National Assembly was necessary. However, from the point of view of constitutional politics, recourse to the Grand National Assembly would have slowed down the speed of preparation for EU accession and could have even led to a long-term stalemate in the Bulgarian EU integration process.

1.2.2 The 1991 Bulgarian Constitution provides for a two-track amendment procedure. The first, difficult amendment procedure concerns key constitutional issues enlisted in Art. 158 of the Constitution. These include the adoption of a new Constitution, the substantial acquisition or loss of state territory and the ratification of international treaties for such territorial shifts, the amendment of the form of governance and the form of territorial distribution of power, the amendment of rules concerning the hierarchical status of international treaties and the direct effect of the Constitution, the irrevocability of human rights as well as changes to the model for constitutional amendment. These amendments can be adopted only by the Grand National Assembly. The form of governance and form of territorial distribution of power are key concepts since they represent the general models for the horizontal and vertical separation of powers (statuses, functions and competences) enshrined in the Constitution.

\footnotetext{
${ }^{11}$ Here and subsequently the cases can be accessed at the Court's website http://constcourt.bg/acts . The text of the judgments have been translated by the authors, as no English translations were available at the time of writing.
} 
This procedure is rather difficult to accomplish because it requires the adoption of a decision for summoning the Grand National Assembly. It has to be adopted by the National Assembly by a qualified majority of two-thirds of all MPs, followed by dissolution of the ordinary Parliament and election of this special constituent assembly. Furthermore, the Grand National Assembly must adopt the proposed amendments by a two-thirds majority of all MPs, of whom there are 400 and not 240 as in the ordinary Parliament, in three readings on three different days.

The second amendment procedure is for other constitutional provisions and is to be carried out by the Parliament. The National Assembly must adopt the draft bill for constitutional amendment in three readings held on three different days with a three-quarters majority of all MPs. A constitutional amendment can be initiated by the President, or by one-quarter of the MPs, if the amendment is to be adopted by the National Assembly, or by one-half of the MPs in case of amendment by the Grand National Assembly.

The Bulgarian Constitution is considered rigid due to the fact that its most important provisions can be amended only by a special institution elected with the sole purpose of functioning as a forum of the pouvoir constitutant. As previously mentioned, the decision to call elections to the Grand National Assembly has to be taken by the National Assembly by a two-thirds majority of all MPs. Thus, a very high degree of political consensus is required both for taking a decision to summon the Grand National Assembly and for the adoption of the constitutional amendments by this convent. Since 1990-1991, no Grand National Assembly has been summoned, notwithstanding the fact that such suggestions have been made from time to time by politicians and by some scholars. These appeals have pertained to both EU related proposals for constitutional amendment as well as to other aspects for possible improvement of the Constitution.

The border between the two types of provisions and constitutional amendment procedures is not as clear and stable as it might initially seem. This is due to the fact that the notions 'form of governance' and 'form of territorial distribution of power' can be rather vague in a theoretical and comparative perspective when it comes to their concrete institutional components. The abstractness of these concepts in combination with the right of the Constitutional Court to give an abstract interpretation of the constitutional provisions has shifted the demarcation line in a number of interpretative decisions. The concepts were first clarified by the Court as a precondition for amendment of the Constitution in the course of the preparation of Bulgaria's EU accession. In Decision No. 3 of 2003, the Constitutional Court defined the 'form of governance' and 'the form of territorial distribution of power' very broadly by invoking the idea of change within the balance of government. Hence, all possible amendments and adjustments of the status, functions and competences of the Parliament, Government, President and Vice President, Constitutional Court, courts, state prosecutors' offices and state investigators' offices should be regarded as related to the form of statehood. On a strict interpretation of this decision, one could infer that most eventual constitutional amendments should be adopted by convening the Grand National Assembly. 
However, one year later the Constitutional Court, in its Decision No 3. of 2004, ruled that none of the necessary amendments in the context of the EU accession of Bulgaria concerned the form of governance or the form of territorial distribution of power, and thus could be passed by the National Assembly instead of the Grand National Assembly. These potential amendments included the adoption by the EU institutions of acts with supranational, direct and universal effect; the right of EU citizens and companies to acquire land ownership in Bulgaria; the provision of EU citizenship and the consequences that stem from it; the competence of the National Assembly to exercise preliminary control over the drafting of acts of the EU before their adoption; the extradition of Bulgarian citizens to a foreign state or an international court under the conditions of a treaty; and the extension of the indicators for equality of Bulgarian citizens in accordance with the Charter on Fundamental Rights of the EU.

It is clear that in the light of Decision No. 3 of 2003, the granting of the direct and universal effect of EU acts and the extension of parliamentary control over the Government should have been deemed an amendment in the form of statehood. According to the decision,

form of governance has to be interpreted extensively ... it must include the competences and functions of the state institutions insofar as the balance between them is concerned based on the observation of the main principles on which the state is founded - the people's sovereignty, supremacy of the Constitution, political pluralism, separation of powers, rule of law and judicial independence.

It is obvious that the direct and universal effect of EU acts concerns the issue of constitutional supremacy, whereas parliamentary control is a core issue of parliamentarianism and is an important dimension of the relations between the Parliament and the Government. However in the aftermath of Decision No. 3 of 2004, a set of constitutional amendments was adopted by the National Assembly, which mostly coincided with the issues addressed by the Constitutional Court. Hence, the easier constitutional amendment procedure was put into practice for the purpose of adjusting the Constitution to the needs of EU membership.

It is also of interest to note that the extremely restrictive position adopted in Decision No. 3 of 2003 was changed to some extent by Decision No 5. of 2005, by virtue of which many important and far-reaching amendments regarding the judiciary were declared to be amendments that do not pertain to the form of governance as long as they do not affect the constitutional balance of powers. Thus, the Constitutional Court opened the way for a reform of the judiciary through constitutional amendments that were adopted by the National Assembly. The reform of the judiciary concerned EU membership indirectly, as Bulgaria's EU entry was conditional on strengthening of the rule of law.

1.2.3 The background to the amendment is addressed in Sects. 1.2.1 and 1.5.1.

1.2.4 One area where, in the experts' view, the Constitution may need amendment is the provision of a clearer stance on the hierarchical status of EU law in the system of the sources of law. At the moment, the 1991 Constitution does not contain any 
direct provisions concerning this issue. The current situation allows for two different interpretations. The first is that EU law does not have supremacy over the Bulgarian Constitution because, as with international treaties, it ranks above all domestic legislation except the Constitution. The allocation of EU law on the level of international treaties is problematic not only because most EU law, i.e. secondary EU law, is not adopted in the form of an international treaty. If EU law is regarded as a system of international treaties, major problems could occur in the case of a collision between EU law and an international treaty adopted outside the EU.

The second interpretation might be that EU law has supremacy over all national sources of law, including the Constitution. Such reflection might be founded on the case law of the Court of Justice of the European Union (CJEU) (e.g. Internationale Handelsgesellschaft ${ }^{12}$ and on the implicit suggestion that these cases are internally legitimised by the EU integration clause of the Bulgarian Constitution. However, such interpretation is problematic due to the lack of a clear normative basis in the text of the 1991 Constitution. The Constitutional Court has not addressed this matter.

The problem of the status of EU law in the hierarchy of norms also concerns the competence of the Bulgarian Constitutional Court to exercise control. According to the Constitution, the Constitutional Court can control the constitutionality of international treaties prior to their ratification, as well as the compliance of Acts of Parliament and of the President with international treaties and the general norms of the international law. There have been some cases in which the Constitutional Court has had to decide whether parliamentary statutes are in compliance with EU law. Hence, by admitting the cases, the Constitutional Court has implicitly assumed that EU law has the status of international treaties.

The relative indecisiveness of the Bulgarian Constitution regarding the issue of the hierarchical place of EU law in the Bulgarian legal system allows for its initial flexibility and openness towards the dynamic developments surrounding the issue of the delimitation between the national and supranational legal orders. However, it would be preferable if the Bulgarian Constitution were to explicitly provide the position of EU law in the system of sources of law and its relation to the Constitution itself and to international treaties.

\subsection{Conceptualising Sovereignty and the Limits to the Transfer of Powers}

1.3.1 The integration clause of the Bulgarian Constitution stipulates: 'The Republic of Bulgaria participates in the construction and the development of the European Union'. The transfer of competences contained in the Constitution to the EU by international treaties has to be authorised by the parliamentary ratification of a

${ }^{12}$ Case C-11/70 Internationale Handelsgesellschaft [1970] ECR 01125. 
statute adopted by a two-thirds majority of all MPs. Hence, the only procedural difference in comparison to other statutes through which the National Assembly ratifies international treaties, is the qualified majority.

Whilst the transfer of constitutional competences is usually an expression of the will of the constituent power, this would not appear to be reflected well in the type of procedure envisaged by the constitutional legislator, by the 2005 amendments, for the transfer of constitutional competences to the EU. Instead of procedures which involve the constituent power as in the case of a constitutional amendment, the transfer of constitutional competences to the EU is subject to the procedure applicable for the ratification of treaties, i.e. a procedure that is a manifestation of a constituted power albeit with higher procedural hurdles. Frequently, such transfer of competences may even result in a further transfer of sovereignty to the EU. The paradox is that while constitutional amendments concerning small adjustments and incremental reforms of provisions of secondary importance have to overcome higher procedural hurdles, the transfer of constitutional powers to the EU can be done much more easily. In other words, the introduction of constitutional amendments caused by internal considerations is much more difficult in comparison to the transfer of competences to the EU, even if in some cases summoning the Grand National Assembly might also be deemed necessary.

Additionally, the constitutional legislator has preferred to use the concept of transfer of competences and not of sovereignty or sovereign rights, which in terms of wording is a compromise that formally spares and preserves national sovereignty. However, the procedural safeguards for such transfer of constitutional competences are much lower in comparison to the procedural hurdles for constitutional amendment. This is rather problematic because the transfer of competences to the EU as well as the EU's increasing constitutionalisation influence the national constitution sometimes to a greater extent than the formal amendment of constitutional provisions that are of secondary importance.

As noted in Sect. 1.2.3, the Constitution does not contain any explicit provisions on the supremacy and direct effect of EU law. Different interpretations regarding the hierarchical relations between the Constitution and EU law can be used due to the lack of sufficient clarity on this issue. The constitutional restraint in regulating this subject matter has not been remedied by decisions of the Constitutional Court, which has only ruled that the supremacy, universal and direct effect of EU law does not touch upon the issue of the form of governance of Bulgaria. On the other hand, the silence of the Constitution can also be interpreted as tacit approval of the supremacy and direct effect of EU law based on the decisions of the CJEU, and as strategic waiting for clearer solutions to be taken on the European level.

1.3.2 The Bulgarian Constitutional Court has taken a very EU friendly stance towards the issue of transfer of sovereignty. The Constitutional Court ruled in the reasoning of Decision No. 3 of 2004 that 'the amendment of the Constitution imposed by the necessity of its adaptation to the requirements of the full EU membership of Bulgaria does not infringe its sovereignty'. With reference to Art. 1, para. 2 of the Constitution, the Court ruled as follows: 
All state power stems from the people. It is exercised by the people directly or through the institutions provided in the Constitution. Consequently the people can voluntarily delegate part of their sovereign rights through the National Assembly that is elected by them and in accordance with the requirements of an international treaty to which Bulgaria is party.

The accession of the Republic of Bulgaria to the EU became effective after the ratification of its accession treaty by the National Assembly. This ratification is an expression of the people's will. The EU membership that stems from it aims at protecting its state sovereignty and national security. The integration process is based on a shared exercise of sovereignties by virtue of which the Member States accomplish together some of their tasks and thus make a shared use of their sovereignties. The sovereignty of the Republic of Bulgaria is not in peril since the adoption of decisions and legal acts by the EU institutions with their supranational, direct and universal effect will be done with the participation of the Republic of Bulgaria.

This argumentation of the Bulgarian Constitutional Court clearly demonstrates that it understands the principle of state sovereignty and the principle of the people's sovereignty not in their absolute form, but rather in a modified and flexible version that are adaptable to the needs of EU integration. Thus, the Constitutional Court opened the way for the application of more modern concepts of sovereignty, such as the theory of pooling and sharing sovereignty. ${ }^{13}$

1.3.3 The Constitution explicitly tackles neither state sovereignty nor the eventually emerging allocation of sovereign competences at EU level. The Constitution pronounces the principle of the people's sovereignty and prohibits its usurpation by citizens, political parties, organisations or state institutions. Hence, it implicitly prohibits such usurpation also by EU institutions, EU officials and European political parties, although it is doubtful whether they could be subsumed under the above-mentioned categories. The historical and strictly textual interpretation should be replaced with teleological interpretation because it is obvious that the Constitution cannot serve as a safeguard against the usurpation of sovereignty by national political players while at the same time having no such function against European ones.

There is no extensive debate in Bulgaria regarding issues such as constitutional identity and judicial dialogue. The constitutional identity is an emerging issue in the Bulgarian scientific realm. There are articles tackling the issues of primacy and supremacy of EU law. ${ }^{14}$ In a recent study, Evgeny Tanchev delimits the scope of issues that should be deemed as falling within the scope of constitutional identity. Furthermore, he suggests that EU law prevails over domestic law (including the national Constitution) in areas of transferred sovereignty under the conditions that 'the national constitution is below the standard of EU law or national constitutional

\footnotetext{
${ }^{13}$ The pooling and co-existence of sovereignties that has been suggested as appropriate also in the Bulgarian case by some theorists. Tanchev 2003, pp. 281-282, especially with reference to MacCormick 1993, p. 16.

${ }^{14}$ Drumeva 2009, pp. 101-102; Tanchev 2014, p. 69-75.
} 
limitation exceeds or poses a higher restriction than EU law' and 'EU institutional law does not conflict with the national constitutional identity. ${ }^{15}$

There is also no systematic jurisprudence of the Constitutional Court on the limits of transfer of competences to the EU level of governance that would be at least to some extent comparable to that of the constitutional jurisdictions of some other EU Member States. The three above-mentioned decisions of the Bulgarian Constitutional Court are concerned more with the internal question of which institution of the Bulgarian constituent power is competent to adopt EU related constitutional amendments, rather than with delimiting lines between the national and supranational levels of governance.

The Constitution itself also does not impose any explicit substantial limits to the transfer of competences or even sovereignty to the EU. However, as was seen in Sect. 1.2.1, constitutional amendments pertaining to issues such as the supremacy of the Constitution, the form of governance and the form of territorial distribution of power can be adopted only by the Grand National Assembly. The Constitutional Court's jurisprudence on these has indicated the existence of a very thick 'red line': a potential change in the EU's nature would influence these key elements of Bulgarian constitutionalism and require the convening of the Grand National Assembly.

1.3.4 The supremacy and the direct effect of the Constitution are explicitly proclaimed in Art. 5, paras. 1 and 2 of the Constitution. According to Art. 5, para. 4, international treaties that have been ratified, published and have entered into force have the position immediately below the Constitution but prevail over all other domestic sources of law. The Constitution does not contain any provisions concerning the hierarchical status of EU law; one of the reasons for this silence is the fact that the supremacy of the Constitution can be amended, and the supremacy of EU law over the Constitution or international treaties can be proclaimed only by the Grand National Assembly. Summoning such Assembly was deemed to be very difficult in the pre-accession period, so the direct effect and primacy of EU law had to be based on an indirect constitutional dialogue between the Constitutional Court and the CJEU. The Bulgarian Constitutional Court has taken its pro-integration decisions bearing in mind the CJEU's jurisprudence on the supremacy of EU law. The Bulgarian Constitutional Court emphasises EU-friendly interpretation and generally seeks to avoid undermining EU law in practice. This is the case also with other Bulgarian courts.

\subsection{Democratic Control}

1.4.1 The key issues regarding the competence of the National Assembly to participate in EU policy-making are regulated in the amended Art. 105, paras. 3 and 4

15 Tanchev 2014, p. 72. 
of the Constitution. ${ }^{16}$ The detailed rules are provided by Chap. XI of the Regulation for the Organisation and the Activity of the National Assembly (Regulation), and these broadly reproduce the provisions of the Protocol on the Role of National Parliaments in the European Union and the Protocol on the Application of the Principles of Subsidiarity and Proportionality. Although the provisions of the Constitution and of the Regulation formally enhance the role of the Bulgarian Parliament and upgrade the set of tools at its disposal for influencing governmental activity, the political practice does not differ from that in other Southern, Central and Eastern European Member States in which the domination of the national government over the national parliament in the EU decision-making process in terms of advantages in information, organisation, expertise and motivation is obvious. $^{17}$

The main rules in the Regulation are as follows. The Committee on EU matters and Control over EU Funds has the right to impose a parliamentary reservation on EU draft acts that are included in the Annual Working Program of the National Assembly on EU matters. The imposition of a parliamentary reservation may be initiated by this committee or by any other standing committee of the Parliament. The parliamentary reservation obliges the Government to refrain from expressing any statement regarding the act concerned in the Council of the EU during a certain term, until the National Assembly pronounces on this issue. The Regulation of the current 43th National Assembly provides that the Government cannot be restrained from acting by a parliamentary reservation during the third session of the preparatory body of the Council which is working on the draft EU legislation. In theory, this competence increases the role of the National Assembly in the decision-making process of the EU. However, it is of marginal importance in political practice.

There are several institutions that can perform control over the activity of the Bulgarian Council of Ministers and over the Prime Minister, the ministers and other executive power institutions regarding their planned or past activity in the EU. These are the plenum of the National Assembly, the standing parliamentary committees and, more precisely, the specialised permanent parliamentary Committee on EU Matters and Control over EU Funds, as well as individual MPs. There are two groups of instruments for parliamentary control. The first encompasses the general tools for parliamentary control over governmental activity: questions, interpellations, parliamentary inquiries and deliberations as well as votes of confidence and non-confidence. The second group includes specialised forms for EU related parliamentary control. Some of them concern a priori parliamentary control, whereas others result in a posteriori parliamentary control. The a priori control consists of

\footnotetext{
${ }^{16}$ According to Art. 105, paras. 4 and 5 of the Constitution, '[t]he Council of Ministers shall inform the National Assembly on issues concerning the obligations of the Republic of Bulgaria resulting from its membership in the European Union. When participating in the drafting and adoption of European Union instruments, the Council of Ministers shall inform the National Assembly in advance, and shall give detailed account for its actions.'

${ }^{17}$ Kiiver 2006, and O’Brennan and Raunio 2007.
} 
the obligations of the Bulgarian Council of Ministers: to inform the National Assembly in advance about the duties of Bulgaria arising from its EU membership and regarding governmental activity in the course of the preparation and adoption of EU legal acts; to present the Annual program for Bulgaria's participation in the decision-making process of the EU for approval in Parliament; to send the drafts of EU legal acts as well as framework positions on such acts to Parliament and to inform Parliament of circumstances that warrant amendments to such positions. The draft acts of the EU which are submitted to Parliament by the Government are distributed to the standing parliamentary committees. Moreover, the Committee on EU Matters and Control over EU Funds carries out preliminary hearings of candidates proposed by the Government for EU positions.

Last but not least, the National Assembly carries out control of observation of the principles of subsidiarity and proportionality in accordance with the above-mentioned EU Protocol. It participates in the mechanisms for evaluation of the execution of EU policies in the area of freedom, security and justice, in the political control of Europol and the assessment of the activities of Eurojust.

The Prime Minister is obliged to present a report to the plenary session of the National Assembly at the beginning of each six-month EU presidency period. It consists of a summary and assessment of the results of the previous presidency and of the tasks and expectations regarding the upcoming presidency of the EU. The National Assembly may ask the Prime Minister to also present the position of the Republic of Bulgaria in forthcoming meetings of the European Council.

The a posteriori parliamentary control consists in the obligation of the Government to introduce a report on the activity of the Government in the adoption of EU legal acts. This must include an explanation for any deviations from the initial Bulgarian position which have resulted in EU rules that differ from those set out in the initial position.

1.4.2 The Constitution does not provide for referendums on the Constitution, the EU or international treaties, but also does not prohibit them. The Direct Participation of Citizens in State Power and Local Self Government Act prohibits constitutional referendums on matters falling within the competence of the Grand National Assembly, but allows for such referendums concerning the competence of the National Assembly. In any case, these legislative provisions may raise doubts with regard to their constitutionality on the grounds that if only the principle of the people's sovereignty is taken into account, then the prohibition of some constitutional referendums is not possible. On the other hand, the permission for constitutional referendums falling within the competence of the National Assembly could be deemed unconstitutional because the Constitution itself creates a fully fledged model for its amendment that does not provide for a referendum. In addition, the Direct Participation of Citizens in State Power and Local Self Government Act allows for referendums for ratification of international treaties but prohibits referendums for their denouncement.

Consequently, it is possible that in the future a potential stalemate in Bulgarian EU integration could be overcome by a referendum or, on the contrary, a 
referendum might be used as a device for blocking a further deepening of Bulgaria's participation in EU integration.

Bulgaria was among the few European countries that did not hold an EU accession referendum. This is to some extent difficult to explain since, according to sociological public opinion surveys, Bulgarian citizens were very pro-European at the time of ratification of the Accession Treaty. Moreover, the problems that were experienced in other candidate countries that entered the EU through parliamentary ratification instead of direct democratic approval of the EU accession treaty did not exist in Bulgaria.

\subsection{The Reasons for, and the Role of, EU Amendments}

1.5.1-1.5.2 The EU related amendments in the Bulgarian Constitution which were adopted during the period 2003-2007 have been neither very extensive nor negligible. Their moderate scope and content was predetermined by a desire to demonstrate and provide a degree of legal reform that was deemed absolutely necessary for the EU accession of Bulgaria, i.e. the EU integration clause, the permission of EU citizens to buy land and the provisions for parliamentary control over the EU related activity of the Government. In addition to the constitutional amendments that were directly related to EU accession and membership, other parts of the Constitution were also subjected to reform. These amendments were motivated by a desire to adapt the Bulgarian Constitution to the rule of law and democracy standards that were considered inevitable for EU membership in the framework of the Copenhagen Criteria.

Whereas the constitutional amendment procedure for some of the amendments would have been very tough, the need to convene a special body, the Grand National Assembly, was avoided through decisions of the Constitutional Court. These decisions not only enabled the creation of the necessary legal basis for the integration of Bulgaria in the EU but also opened the way for a reform of the judiciary which was and still is very high on the Bulgarian political agenda.

Along with the above-mentioned Constitutional Court decisions and the political will for EU accession and constitutional reform, the public debate among scholars, politicians and civil society activists also influenced the constitutional reforms. The constitutional culture in Bulgaria has never been prohibitive for radical, drastic and even dramatic constitutional amendments. The great political and legal turbulences that Bulgarian society experienced during the 1990s as well as the general permissive consensus for 'more Europe' in general and the EU as its most clear expression in particular, allowed for the unproblematic and rapid adoption of the constitutional amendments. In fact, there was almost no opposition to these amendments either in the scientific literature or in the political discourse. The fact that Bulgaria entered the EU at a relatively late stage made it possible for Bulgaria to use the experience of the older Member States as well as to take the acquis communautaire into account. 
The driving force behind the constitutional amendments was the political will of the predominant part of the Bulgarian political elite and society to join the EU. All reform efforts were directly or indirectly aimed at the achievement of this key goal of Bulgarian society, which dominated the Bulgarian political agenda from the end of the 1990s. Some of the amendments were also to some extent a result of internal constitutional and political debates. This is particularly true for the constitutional reform of the judiciary. The debates were centred predominantly on several issues: the status of state prosecutors and state investigators in the system for separation of powers, the immunity of magistrates, the structural reform of the Supreme Judicial Council and the role of the Minister of Justice. These constitutional amendments were prepared in close cooperation with experts provided by the European Commission and the Venice Commission of the Council of Europe. The reforms were accompanied by extensive scientific and political debate.

1.5.3 The national constitutions will surely remain the key projection of national sovereignty, collective personal identity and political self-consciousness of the people in Europe for a very long time, and maybe even forever. Precisely because of this central aspect of their nature, national constitutions are also the only legitimate devices for opening statehood to supranational levels of public power. Hence, the so called 'opening function' of the constitution ${ }^{18}$ will constantly grow in importance because the constitutions will have to provide the central channel for EU law and international law influences, and will have to serve as the most prominent linkage between the multiple levels and spheres of governance.

If national constitutions were to be neglected, this would lead to an increased delegitimation of European and global governance. This is, on one hand, due to the fact that it would be difficult to re-establish the social preconditions for political cohesion and political obedience on the supranational levels that were necessary for the emergence and establishment of the constitutional civilisation of the nation state. On the other hand, the non-reflexivity of national constitutions regarding issues of EU, multilevel and global governance would diminish their regulative role. ${ }^{19}$ Thus, the nation states would be exposed to the results of the supranationalisation of policy making, the national political actors would be entrenched in 'nested games' ${ }^{20}$ while at the same time they would suffer from legitimacy and efficiency deficits.

Hence it is absolutely necessary for national constitutions to reflect the status quo and even to try to anticipate the tendencies that will emerge both with regard to the

\footnotetext{
${ }^{18}$ Klein 1983, pp. 21-22.

${ }^{19}$ Grimm 2010, p. 4; Peters 2005 p. 41; Peters 2006, p. 580.

${ }^{20}$ The theory of the 'nested games' has been developed by G. Tsebelis. It is an attempt to create a model for explanation of the behaviour of constitutional institutions when they are embedded in a vertically intertwined hierarchy and/or network of institutional interactions between the subnational, national, supranational and non-state players. The idea is to conceptualise the predetermination of the political behaviour of the institutions on the lower levels as systemically influenced by the preferences of the institutions that are allocated on the upper levels of the territorial power scale. See Tsebelis 1990.
} 
institutional infrastructure and the functional processes which are developing on the supranational levels of decision-making. The tacit approval of supranational constitutional and political novelties, i.e. by non-resistance on the part of the national constitutional legislators, constitutional and supreme courts, parliaments and governments could be just a tactical exercise but not a long-lasting attitude. Otherwise the national constitutions may well become obsolete, both 'from above' because they would impede common supranational projects and would turn into distorting relics from the past, and 'from below', due to the fact that they would lose their regulative and convincing force for the nations in general and the citizens in particular.

The democratic deficit of the EU, the development of negative phenomena such as deparliamentarisation, de-democratisation or even a 'hollowing out of national constitutions' can hardly be addressed on a national level as a mosaic solution on a case-by-case and state-by-state basis. The problems of the European representative democracy in the context of the existing degree of EU integration cannot really be resolved without a common and fully co-ordinated solution at EU level. Hence, attempts to reinforce and improve the standing of the national parliaments in relation to the national governments and the EU power machinery based on executive domination and 'agencification', will be doomed to failure.

If the degree of European integration were to remain at its current level, then a real representative system would have to be achieved at EU level. This aim requires the further parliamentarisation of the EU system, the establishment of a more functional party system and the strengthening of the role of the President of the EU Commission, whose legitimacy should be re-established on a more direct democratic basis.

\section{Constitutional Rights, the Rule of Law and EU Law}

\subsection{The Position of Constitutional Rights and the Rule of Law in the Constitution}

2.1.1 The Bulgarian Constitution contains an extensive Chap. II that is devoted to human rights and citizens' duties. The constitutional provisions on human rights in Bulgaria have been inspired by international human rights standards. The most important sources of inspiration are the Universal Declaration of Human Rights, the International Covenant on Civil and Political Rights, the International Covenant on Social, Economic and Cultural Rights and the European Convention on Human Rights and Fundamental Freedoms (ECHR). Hence, the UN and the Council of Europe have been the key international organisations that have influenced the constitutional drafting of human rights in Bulgaria, whereas the EU had not developed extensive human rights standards at the time of drafting the Constitution. Because the standard of constitutional proclamation of human rights was 
sufficiently high, there was no need for a thorough human rights reform later in the course of EU accession.

The 1991 Constitution provides for most civil, political, economic and cultural rights. It also includes constitutional duties. It contains all of the generations of human rights according to the theory of Vazak. ${ }^{21}$ Moreover, all four statuses of man and of the citizen that were proposed by G. Jellinek ${ }^{22}$ are incorporated in the Constitution.

In addition to Chap. II, the Constitution contains further human rights provisions. For example, key human rights and guarantees are provided in Chap. VI, 'Judicial Power'. The Bulgarian Constitution is interpreted to implicitly include all of the classic general principles of law, such as legal certainty, protection of legitimate expectations, non-retroactivity, proportionality, the competence of state institutions, etc. Moreover, it also contains specific provisions for the key elements of due process of law, i.e. nullum crimen nulla poena sine lege praevia Art. 5(3)); right to appeal (Art. 122); right to be heard by a jury in the first instance in the most important criminal cases (Art. 123); right to defence (Art. 30(3) and (4), Art. 56 and Art. 122); right to a public hearing (Art. 121(3)) and procedural equality (Art. 121(1)). Most of these provisions are in the chapter on judicial power, some are in the chapter on human rights, while some are in the chapter on the main principles of the Constitution. The non bis in idem rule is provided by Art. 24 para. 1, point 6 of the Code of Criminal Procedure.

The human rights and general principles enshrined in the Constitution are in principle directly applicable and enforceable in courts. However, some are by their nature non-self-executing; such rights do not enjoy immediate judicial protection but they may serve as a source for legal argumentation for the courts. The Constitution proclaims its supremacy and direct effect. The courts and the state prosecutors are to suspend judicial proceedings and file a petition with the Supreme Court of Cassation, the Supreme Administrative Court or the State Prosecutor General in the case of the presumed unconstitutionality of an Act of Parliament. These three institutions have the right to petition the Constitutional Court, which is the only institution that can proclaim an act unconstitutional. Consequently, although constitutional rights are theoretically guaranteed by constitutional supremacy, in practice their observation by Parliament may be guaranteed by the ordinary courts only indirectly through the above-mentioned lengthy and complex procedure.

2.1.2 According to Art. 57 para. 1 of the Constitution, human rights are irrevocable. The rigidity of this declaration is however rather of political than of legal nature because the Constitution does not contain any unamendable provisions (eternity clauses). This is due to the fact that Art. 57 para. 1 of the Constitution can be amended or even abolished by the Grand National Assembly, although this would be very unlikely from a political and practical point of view.

\footnotetext{
${ }^{21}$ Vazak 1984, pp. 837-850.

22 Jellinek 1905, pp. 105-125.
} 
The irrevocability of human rights might be regarded as a limit to the transfer of power to the EU. However, it is a very broad limit which would not have any practical consequences, since a situation where human rights would be deemed revocable and would be abolished in EU law or in national law due to EU influence is rather unthinkable. The irrevocability of human rights is a very wide and vague limit also because it is not specific and addresses the abolition of human rights as a constitutional category. The Constitution provides for the irrevocability of the 'basic' rights. Thus, it perhaps presumes that these are actually classical human rights, i.e. civil and political rights. Consequently, amendments in the shape and scope of human rights design will generally not be understood as infringements of the irrevocability of human rights as a constitutional principle and as a limit to the transfer of powers to the EU.

Article 57 para. 3 of the Constitution allows temporary limitation of some constitutional rights in case of war, a state of emergency or state of siege by virtue of parliamentary statute adopted by the National Assembly. Several key civil rights such as the right to life, the prohibition of torture and other inhuman and degrading treatment, the right to personal freedom and integrity, the right to privacy and the freedom of conscience, thought and religion are excluded from the aspects of human freedom which may be limited.

Last but not least, Art. 31 para. 4 of the Constitution provides that limitations of the rights of the defendant which exceed the necessary degree for the due functioning of the criminal process, are inadmissible. This is a specific reflection of the proportionality principle in the context of criminal procedure that is explicitly provided by the Constitution.

2.1.3 The rule of law in its continental version of Rechtsstaat is one of the fundamental principles of the Bulgarian Constitution. It is explicitly enshrined in the Preamble as well as in Art. 4 para. 1. Moreover, the typical components of the rule of law are provided by the Constitution as well as by legislation. Human rights and most of their guarantees, such as constitutional and administrative justice, the ordinary and specialised courts, the prohibition of extraordinary courts, the Ombudsman, the limited version of indirect constitutional complaint via the national Ombudsman, the principle of the competence of state institutions (the principle that each state institution is to act only within its competence), the non-retroactivity of criminal and tax law, the key principles of due process, the supremacy of the Constitution, the primacy of international law over sub-constitutional legislation and of the Acts of Parliament over governmental and other executive acts are enshrined in Bulgarian constitutional law. There is no direct constitutional complaint, but its introduction has been a matter of long-standing discussion in the academic debate. The most important arguments in favour are that it would enhance the protection of constitutional rights and allow the Constitutional Court to develop human rights jurisprudence. The key argument against the introduction of a constitutional complaint is that it might lead to a case overload for the Constitutional Court. 
The principle of the rule of law as provided by the Bulgarian Constitution and legislation is justiciable due to the direct effect of constitutional provisions and the fact that they are further developed and implemented by Acts of Parliament and the other sources of law. Of course the more concrete and self-executing the elements of the rule of law, the more applicable they are in lawsuits. This fact does not prevent the citizens and legal entities who are parties to a pending lawsuit from basing their arguments on more general stipulations grounded on the rule of law. There is no statistical data on how frequently the rule of law is used as an argument by applicants (in contesting legal acts) and by the courts (in exercising judicial review). However, one can suppose that in the different legal discourses there is a rather frequent use of the rule of law either as the core element of a general argumentative strategy or as an additional argument in support of the claim. Sometimes the argumentation is grounded not on the rule of law as a holistic concept but on one or more of its elements.

Access to courts and the right to judicial review are constitutionally entrenched and are regarded as core elements of the rule of law in Bulgaria. According to Art. 31 para. 1 of the Constitution, '[a]nyone charged with a crime shall be brought before a court within the time established by law'. According to Art. 30 para. 3 of the Constitution, '[n]obody can be detained for more than 24 hours without a permission of an institution of the judiciary. The institutions of the judiciary are informed for each detention from its very beginning'. Moreover according to Art. 120 para. 2 of the Constitution, '[c]itizens and legal entities shall be free to challenge any administrative act which affects them, except those listed expressly by the laws'. Last but not least, Art. 122 para. 1 of the Constitution grants all persons the right to legal counsel at all stages of a trial.

Article 5 para. 5 of the Constitution stipulates that all normative acts have to be published in the State Gazette (the Official Journal of Bulgaria) to be valid. They enter into force three days after publication except if they provide for some other vacatio legis. Legal certainty is a key principle of Bulgarian constitutional law. The central role in upholding this principle is played by the Supreme Court of Cassation and the Supreme Administrative Court, which can issue interpretative decisions in case of controversial or incorrect practice of the courts of first and second instance.

The retroactivity of criminal law is explicitly prohibited by Art. 5 para. 3 of the Constitution which stipulates that no one can be. convicted for an action or inaction which at the time it was committed, did not constitute a crime. According to Art. 2 of the Penal Code, for any crime, the law that is in force at the moment it is committed, applies. If another law enters into force before the pronouncement of the sentence, the most favourable norm for the sentenced person must be applied. According to Art. 2 of the Administrative Offences and Sanctions Act, all actions or omissions that constitute an administrative offence, as well as their sanctions, have to be determined by law. Furthermore, Art. 3 of the same Act provides that the Act that is valid at the moment an offence is committed applies, except if a newer Act is more favourable for the offender. Moreover, the non-retroactivity of the tax and financial obligations of citizens is provided by tax legislation. The administration of criminal justice by analogy is prohibited in Bulgaria. 


\subsection{The Balancing of Fundamental Rights and Economic Freedoms in EU Law}

2.2.1 The issue of balancing classic fundamental rights and economic free movement rights has barely been discussed in Bulgarian theory and political discourse. ${ }^{23}$ From the available information it is very difficult to come to a scientifically verifiable conclusion as to whether the Bulgarian courts give priority to classical rights or EU economic freedoms. In general, the Bulgarian judicial discourse is relatively pro-human rights biased. This is the result of more than two decades of training of Bulgarian judges in a pro-human rights discourse. Hence, without any claim of accuracy, one can assume that in the case of a conflict, the protection of human rights would prevail over the guarantee of EU fundamental freedoms.

\subsection{Constitutional Rights, the European Arrest Warrant and EU Criminal Law}

With regard to the following sections regarding the European Arrest Warrant (EAW), it is important to note that the provisions on defence rights and guarantees as well as on judicial review and access to courts are notably strict, detailed and far-reaching in the Bulgarian Constitution, as outlined above in Sect. 2.1.3 on the rule of law. However, as will be seen in the following sections, there has been no real debate on how the European Arrest Warrant and other EU criminal law measures relate to these constitutional provisions.

\subsubsection{The Presumption of Innocence}

2.3.1.1 It is a constant practice of the Bulgarian courts to refuse to pronounce on the substance of the case, including the issue of the innocence or guilt of a detained person who has to be surrendered on the basis of a European arrest warrant. The issue of the presumption of innocence is not considered as relevant if the person is handed over to the state that has issued an EAW for execution of a verdict that has

\footnotetext{
${ }^{23}$ An exception is the chapter on Bulgaria in the Reports of the XXV FIDE Congress, Vol. 1, which was written by Alexander Kornezov. In his report he argues that the Bulgarian Constitutional Court is much more inclined than the CJEU to balance free movement rights with other constitutional rights. He grounds his argumentation on Decision No. 2 of 2011 of the Constitutional Court in which the Court proclaimed some provisions of the Bulgarian Personal Documents Act unconstitutional due to a disproportionate limitation of the right to free movement through constraints based on non-payment of tax duties serving as framework safeguards for some economic and social constitutional rights. Kornezov 2012, pp. 268-270. Although this suggestion is reasonable, we believe that the case law is still insufficient to make sound, justified and broader evaluations on the issue of the balancing of constitutional rights with EU law economic freedoms.
} 
already entered into force. In both cases, the state that has to guarantee the observance of the presumption of innocence is the requesting state because its courts are deciding the substance of the matter. The courts of the surrendering state just control the observance of the formal and procedural prerequisites for the legal accomplishment of the process.

2.3.1.2 The predominant practice of the Bulgarian courts is to approve a European arrest warrant if the formal and procedural requirements are fulfilled. The Bulgarian courts do not evaluate the evidence gathered on the substance of the case. The claims of innocence that are sometimes made by the people that are subject to a European arrest warrant are deemed irrelevant. The Bulgarian courts do not refuse the execution of a European arrest warrant on the basis of such claims. On the basis of the jurisprudence of the Bulgarian courts, a conclusion can be made that they do not regard the European arrest warrants as infringing the presumption of innocence.

\subsubsection{Nullum crimen, nulla poena sine lege}

2.3.2.1 Most of the 32 crimes for which a European arrest warrant can be issued create a very high degree of danger for society. Hence, most of them are defined as criminal offences by the legislation of all EU Member States. Only a few of them possess the potential for incorrect interpretation by the Bulgarian courts due to the vagueness of the terms in which they are formulated. In practice, the Bulgarian courts subsume the broadly formulated offences for which the principle nullum crimen is excluded under the more concrete criminal offences provided by the Bulgarian Penal Code, so as to enable the issuing of European arrest warrants. In many cases the Bulgarian courts point out criminal offences under Bulgarian criminal law for which the person can be held criminally liable, although there are legally granted exceptions from the principle nullum crimen, nulla poena sine lege by the Extradition and the European Arrest Warrant Act that implements the EAW Framework Decision. ${ }^{24}$ The exceptions concern criminal activities which are directed against fundamental social values and interest that are common for all EU Member States. That is why it is very unlikely that there will be a great mismatch between the criminal legislation of the issuing and the executing state; it is also unlikely that the persons who are subject to a European arrest warrant are unaware of the fact that their actions or omissions possess a criminal character.

\subsubsection{Fair Trial and In Absentia Judgments}

2.3.3.1 In absentia judgments endanger the right to defence of the defendant. Personal participation in a judicial trial allows the defendant to give explanations,

\footnotetext{
${ }^{24}$ Council Framework Decision of 13 June 2002 on the European arrest warrant and the surrender procedures between Member States (2002/584/JHA), [2002] OJ L 190/1.
} 
have the last word, present evidence, etc. Hence, with regard to the rule of law, it is highly recommendable that in absentia judgments be avoided as much as possible.

The Bulgarian Extradition and European Arrest Warrant Act was amended in 2011 in order to allow the Bulgarian courts to reject the surrender of a person on the basis of a European Arrest Warrant which aims to execute a sentence of imprisonment or other type of detention that has resulted from a judgment pronounced in his or her absence. A prerequisite for such rejection is a lack of evidence that the person himself or herself caused the situation resulting in an in absentia judgment.

\subsubsection{The Right to a Fair Trial - Practical Challenges Regarding a Trial Abroad}

2.3.4.1 The Bulgarian state does not provide legal or financial aid to its citizens or to persons who have permanent residence on its territory if they are surrendered on the basis of a European arrest warrant. There is only one NGO, the Association for Reintegration of Convicted Persons, which provides aid for the social reintegration of persons who are convicted either in Bulgaria or abroad. However, this organisation does not provide financial or legal aid for the defence of persons surrendered on the basis of a European arrest warrant in the issuing state. It is clear that the establishment of a state or non-state institution providing such aid would enhance the chances of persons who are transferred to another EU Member State on the basis of a European arrest warrant for a proper defence. However, due to financial reasons, it is not very likely that such an institution will be created any time soon.

2.3.4.2 There are no reliable statistics regarding the number of persons who have been extradited to another EU Member State on the basis of a European arrest warrant and subsequently acquitted by its courts. Hence, no comparison between the number of such persons and persons who have been acquitted by the Bulgarian courts can be made.

\subsubsection{The Right to Effective Judicial Protection: The Principle of Mutual Recognition in EU Criminal Law and Abolition of the Exequatur in Civil and Commercial Matters}

2.3.5.1 The constitutional issues concerning the EU mutual recognition instruments have not been extensively discussed in Bulgarian legal theory. Indeed, Bulgaria's report on the Area of Freedom, Security and Justice for the FIDE 2012 Congress notes that '[1]aw enforcement in Bulgaria strongly supported the principle of mutual recognition in criminal matters' and finds that '[c]ompliance with the rights of the accused or defendant in accordance with differences in national legislation should not impede the achievement of cooperation in criminal matters'. ${ }^{25}$ There has been

${ }^{25}$ Panova and Kashumov 2012, p. 213 and p. 220. 
no analysis regarding their compatibility with the principle of the rule of law and the human rights enshrined in the Bulgarian Constitution. There has also been no judicial practice on the constitutional dimension of the EU mutual recognition instruments.

The principles of effective judicial protection and the rule of law can no longer fully be granted the same level of protection as prior to the introduction of the mutual recognition rule in criminal law and the abolition of the exequatur in civil and commercial matters. This is caused by the status of the EU as a project in process of realisation and transition. The achieved degree of EU integration makes the introduction and practical use of EU mutual recognition instruments necessary. On the other hand, they are based on a presumption of equivalence and proximity of the legal systems of the EU Member States, which is far from reality at the present time.

2.3.5.2 There has been no debate in Bulgaria regarding the suitability of transposing mutual recognition from internal market matters to criminal law and civil and commercial disputes. As it has already been mentioned, such mutual recognition is necessary and even inevitable if EU integration is to keep its pace. However, this is rather problematic due to the mismatch between the legal presumptions on which EU law is grounded and the empirical social reality.

2.3.5.3 The shift in the function of the courts from providers of justice and peaceful resolution of conflicts to transmitters of justice and elements in the chains of trust and co-operation in the EU is to some extent a natural result of the rise of supranational constitutionalism and the need for enhanced and more formalised cooperation between different segments of the emerging Europe-wide judiciary system. Hence, this process will inevitably have to deepen, if EU integration is to remain at its current level. That is why it would be necessary to acknowledge the new roles performed by the courts and try to improve the substantial and not just the normative and formal proximity of the rule of law standards existing in the EU Member States.

2.3.5.4 The reinstatement of substantial judicial review of European arrest warrants would infringe the very essence of this institute for judicial cooperation. The provision of such review would institutionalise mutual suspicion regarding the equality of the rule of law standards applicable in all EU Member States. It would put into question the quintessence of the mutual recognition and co-operation instruments. That is why it would be better to abolish these instruments and the European arrest warrant in particular than to provide such institutional devices for mistrust. Another possible solution would be to try to gradually approximate the applicable judicial protection and the rule of law standard throughout the EU Member States. 


\subsection{The EU Data Retention Directive}

2.4.1 The EU Data Retention Directive ${ }^{26}$ was implemented in Bulgaria by amendments to the Electronic Communications Act which were introduced in 2010. There has been no extensive debate in Bulgaria on the constitutionality of these legislative provisions apart from the activity of some NGOs, e.g. Access to Information Program. There have been several decisions of the Sofia Administrative Court and the Supreme Administrative Court concerning the application of the provisions of the Electronic Communications Act in cases initiated by the above-mentioned NGO.

It has to be noted that two of these Decisions of the Supreme Administrative Court, No. 8786 of 16 July 2008 and No. 13627 of 12 November 2008, concern the abolition of articles of a decree for storage and distribution of information which had been issued by the Minister of Interior and the Chairman of the State Agency for Information Technologies and Communications. This decree had been issued prior to the implementation of the EU Data Retention Directive through the Electronic Communications Act. In its complaint, the Access to Information Program argued that some of the provisions of the decree contravened Arts. 32 and 34 of the Constitution concerning the right to private life, the freedom and secrecy of correspondence and other communications as well as Art. 8 of the ECHR.

The judgments were issued after the adoption of the EU Directive but prior to its implementation in the Bulgarian legal order by an Act of Parliament. Initially a chamber of three judges rejected the complaint in Decision No. 8786 of 16 July 2008. However, a chamber of five judges of the Supreme Administrative Court subsequently issued Decision No. 13627 of 12 November 2008. It abolished Art. 5 of the decree due to a lack of clarity regarding the safeguards for the right to defence, and against illegal interference with the right of citizens to private and family life. The Court based its latter decision on the argument that Art. 5 of the decree contravened the above-mentioned articles of the Constitution and the ECHR.

On 15 April 2014, the national Ombudsman petitioned the Constitutional Court to declare the provisions of the Electronic Communications Act (Arts. 250a to 250, 251 and 251a) that implement the EU Data Retention Directive unconstitutional. The Ombudsman claimed that these legislative provisions infringed the right to private life and the freedom and secrecy of correspondence and other types of communications which are enshrined in the Bulgarian Constitution. He argued that the above-mentioned articles of the Electronic Communications Act also infringed the primacy of international treaties as guaranteed by the Bulgarian Constitution because they contravened the Charter of Human Rights of the EU. The Ombudsman contested the constitutionality of the legislative provisions, and not their conformity

\footnotetext{
${ }^{26}$ Directive 2006/24/EC of the European Parliament and of the Council of 15 March 2006 on the retention of data generated or processed in connection with the provision of publicly available electronic communications services or of public communications networks and amending Directive 2002/58/EC, [2006] OJ L 105/54.
} 
with EU law, because the Bulgarian Constitution only grants the Ombudsman the right to approach the Constitutional Court with complaints regarding the unconstitutionality of Acts of Parliament and not on the ground of incompatibility with international treaties or EU law.

The Constitutional Court accepted the case for examination by its Ruling of 12 June 2014. The Constitutional Court adopted Decision No. 2 of 2015 which declares the above-mentioned articles of the Electronic Communications Act to be unconstitutional. It has to be noted that the CJEU's decision of 8 April 2014 in cases C-293/12 and C-594/12 $2^{27}$ was used as a source of argumentation in front of the Bulgarian Constitutional Court. One can also presume that the annulment of the Directive and the declaration of the unconstitutionality of the national implementing Act might begin to serve as a criterion for the Bulgarian system in terms of the acceptability of blanket data retention. Hence, this might be the benefit that stems from this legislative turbulence in the domain of personal data protection.

With regard to the national constitutional provisions, Art. 32 para. 1 of the Constitution provides the following with regard to privacy: 'The privacy of citizens shall be inviolable. Everyone shall be entitled to protection against any unlawful interference in his private or family affairs and against encroachments on his honour, dignity and reputation'. According to Art. 32 para. 2, '[n]o one shall be followed, photographed, filmed, recorded or subjected to any other similar activity without his knowledge or despite his express disapproval, except when such actions are permitted by law'. The secrecy of correspondence is provided by Art. 34 paras. 1 and 2 of the Constitution as follows: 'The freedom and confidentiality of correspondence and all other communications shall be inviolable. Exceptions to this provision shall be allowed only with the permission of the judicial authorities for the purpose of discovering or preventing a grave crime.'

\subsection{Unpublished or Secret Legislation}

2.5.1 As noted in Sect. 2.1.3 on the rule of law, the Constitution stipulates that all normative acts have to be published in the State Gazette to be valid (Art. 5 para. 5). There is no domestic case law on the issue of secret or unpublished EU legislation in Bulgaria. Hence, the problem of whether this is in compliance with the Bulgarian Constitution has not yet emerged. Under the previous 1971 Bulgarian Constitution, some international treaties did not necessarily need to be published. ${ }^{28}$

${ }^{27}$ Joined cases C 293/12 and C 594/12 Digital Rights Ireland and Seitlinger and Others [2014] ECLI:EU:C:2014:238.

${ }^{28}$ According to Decision No. 7 of 1992 of the Constitutional Court, these international treaties were part of the Bulgarian legal system, but they enjoyed the supremacy and direct effect that is granted to international treaties and the generally recognised norms of international law only after their publication. 
Unpublished or secret legislation infringes legal certainty and the legitimate expectations of citizens as well as of the holders of public office. It creates 'legislative swamps' with paths that are known only to the special circles of elites that have participated in the adoption of the secret legislation or are privileged to be informed about it. Secret legislation is to some extent a contradiction in itself, since the main purpose of all legislation is to create general and durable legal standards that have to be known by its addressees in order to enable them to behave in conformity with the law.

The decision of the Grand Chamber of the CJEU in the Heinrich ${ }^{29}$ case resembles Decision No. 7 of 1992 of the Constitutional Court that has already been discussed above. It is unlikely that the Bulgarian Constitutional Court will use the arguments of Decision No. 7 of 1992 for legitimation of future secret or unpublished EU legislation. The reason is that Decision No. 7 of 1992 of the Constitutional Court had to resolve the issue of what was to be done with international treaties that were concluded under a very different political regime and the non-recognition of which might infringe the principle pacta sunt servanda and thus undermine the international credibility of Bulgaria. On the other hand, there is no legitimate ground to believe that there should be secret or unpublished EU legislation because both the EU and its Member States, Bulgaria included, are democratic regimes that observe the principle of the rule of law.

\subsection{Rights and General Principles of Law in the Context of Market Regulation: Property Rights, Legal Certainty, Non-retroactivity and Proportionality}

2.6.1 There have been no cases relating to these issues in Bulgarian practice. However, as was seen above in Sect. 2.1.3 on the rule of law, these provisions are protected in the Bulgarian Constitution. Moreover, there are cases in which the Constitutional Court has used the principle of proportionality as an argument for declaring the unconstitutionality of legislative provisions that also concern EU measures. $^{30}$

\subsection{The ESM Treaty, Austerity Programs and the Democratic, Rule-of-Law-Based State}

2.7.1-2.7.3 The Republic of Bulgaria is not a party to the Treaty Establishing the European Stability Mechanism (ESM Treaty). Hence its provisions are not relevant

\footnotetext{
${ }^{29}$ Case C-345/06 Heinrich [2009] ECR I-01659.

${ }^{30}$ Decision No. 2 of 2011 of the Constitutional Court.
} 
for Bulgaria at present. There has been no discussion about the constitutionality of the ESM Treaty or other proposed measures such as Eurobonds and the Banking Union.

So far Bulgaria has not been subject to an EU bailout or subsequent austerity programme. Hence, no constitutional issues have arisen with regard to democratic control, the rule of law, transparency, balancing the rights of citizens and residents with those of the international creditor community, or other aspects of a possible bailout programme.

\subsection{Judicial Review of EU Measures: Access to Justice and the Standard of Review}

2.8.1; 2.8.3-2.8.6 The Bulgarian courts have a reluctant approach to referring questions for preliminary rulings. The preliminary rulings that have been requested have predominantly concerned taxation issues. The right to submit a preliminary reference to the CJEU has been used mostly by the lower courts and especially by the administrative courts. The Constitutional Court, the Supreme Court of Cassation and the Supreme Administrative Court have still refrained from involvement in direct judicial dialogue with the CJEU. The Supreme Administrative Court has requested a preliminary ruling from the CJEU in only two cases.

It is very difficult to compare the trust in the CJEU and in the domestic courts. A typical attitude of Bulgarian society is that it trusts European institutions more than national institutions. But this is a very general assessment which is related much more to the Zeitgeist than to any reliable scientific data.

There have been very few cases in which the Constitutional Court has tackled issues concerning EU law and domestic legislation implementing EU law. In almost all of these cases, EU law has been used as the criterion for the annulment of potentially contravening domestic legislation. It is only in a case concerning the legislation implementing the EU Data Retention Directive that domestic legislation is being reviewed with regard to its constitutionality; however, at the time of writing in January 2015 this case is still pending in front of the Constitutional Court.

According to statistical data, ${ }^{31}$ during the period 1991-2006, 158 Acts of Parliament have been challenged for their constitutionality in the Constitutional Court. Of these, 79 have been qualified as fully in compliance with the Constitution, 40 have been declared partially unconstitutional and 39 have been declared fully unconstitutional. Moreover, 25 decisions of the National Assembly, 3 decrees of the President of the Republic and 4 international treaties have been subjected to a review of constitutionality in the Constitutional Court. The outcome of the proceedings has been as follows: 15 of the decisions of the National Assembly as well as all of the presidential decrees and all challenged international treaties were

${ }^{31}$ Modeva 1997, p. 573 and Modeva 2010, p. 825. 
declared to be in compliance with the Constitution, 5 of the parliamentary decisions were declared partially unconstitutional and 5 of the parliamentary decisions were declared fully unconstitutional.

\subsection{Other Constitutional Rights and Principles}

2.9.1 No significant EU-related human rights issues have arisen in Bulgarian practice.

\subsection{Common Constitutional Traditions}

2.10.1-2.10.2 When tackling the issue of common constitutional traditions, one has to take into account that this term might denote very different things, such as constitutional and legislative grounds, the jurisprudence of the courts, the empirical behaviour of the people and the state institutions and the legal consciousness and constitutional culture. Moreover, there is a thin and a thick version of the common constitutional traditions. The thin version consists of the resemblance between the legal provisions enshrined in the valid sources of law of the compared constitutional systems. The thick version comprises also the ways these normative provisions are internalised in the thinking and behaviour of the legal subjects. Here one may differentiate between the political and legal culture of citizens and institutional memory, which sometimes results in path dependence.

The thin version of the common constitutional traditions might seem very wide in scope. Due to its formality and the fact that it is focused on the 'law in books', it might include the main principles of constitutional law - democracy, rule of law, separation of powers, sovereignty and to a lesser extent the welfare state, all civil and political rights, some of the social and economic rights and key principles governing the different branches of state power, especially when it comes to the judiciary. To some extent the breadth of these formal and normative aspects of the common constitutional traditions result in the thinness of this version. The integration processes that started after World War II gained momentum from the beginning of the 1980s and reached their culmination in the establishment of a quasi pan-European legal space after the fall of the Berlin Wall led to the production of a series of constitutional reforms at EU, international, national and even subnational level. The increased resemblance between the formal constitutional systems of the European states and the even greater similarity between the constitutional systems of the EU Member States is the result of this intense approximation effort, which was accomplished by international and EU institutions, by nation state bodies, by NGOs and by other institutional and non-institutional actors.

On the other hand, the thick version of the common constitutional traditions is based on the shared belief of the legal subjects - both office holders and citizens - 
that the constitutionally and legislatively enshrined rights, obligations, principles and institutions are justified and have to be observed and implemented in social and legal practice. In other words, the thick version of the common constitutional traditions comprises not only 'the law in books' but also 'the law in action'.

An important problem lies in the question of who is competent and at the same time has the legitimacy to delimit the common constitutional traditions of the EU Member States in a legally binding and valid manner. The functioning of the courts as representative spokesmen of the community of citizens clashes with the classic issue of their democratic legitimacy deficit. Judicial dialogue is a practicable and intelligible method for delimiting the common constitutional traditions and thus of the constitutional consensus in European constitutionalism. The problem is that if the judicial dialogue and its results lack democratic acceptance, it cannot lead to a legally valid result which is sustainable in the long term. In such a case the passive 'permissive consensus' of the citizens is not sufficient in order to guarantee the development of a real or thick version of the common constitutional traditions.

\subsection{Article 53 of the Charter and the Issue of Stricter Constitutional Standards}

2.11.1 There has been no extensive discussion in Bulgaria on Art. 53 of the Charter and the issue of the application of stricter constitutional standards. We believe that Art. 53 of the Charter is a sufficient legitimation for the application of national human rights standards if they are higher than EU standards. It is true that national law, including national human rights law, should not serve as an instrument for undermining EU integration. However, the achievements not only of the distinct Member States or the ECHR but also of European constitutional civilization in general might be endangered if the EU and its institutions start to systematically diminish the standard of human rights protection with teleological excuses based on efficiency arguments.

It has to be taken into account that Art. 53 of the Charter is to some extent a product of the judicial dialogue between the CJEU and the national constitutional courts. It codifies an important principle in EU primary law, namely that the national standards for human rights protection must be respected by the EU institutions, and that EU standards should not be lower than these national standards. Furthermore, Art. 53 permits the application of higher national human rights standards. Hence, although the decision in the Melloni ${ }^{32}$ case has its logic in the context of the European Arrest Warrant, it gives rise to issues regarding its legitimacy in view of the principle of the rule of law.

32 Case 399/11 Melloni [2013] ECLI:EU:C:2013:107. 


\subsection{Democratic Debate on Constitutional Rights and Values}

2.12.1 There has been no intense debate in Bulgaria either regarding the adoption and implementation of the European Arrest Warrant Framework Decision or with regard to the EU Data Retention Directive. These key events concerning the rule of law in the EU were passively received by the politicians, the academia, the legal community and the broader public. This is due to the general EU-optimistic attitude in Bulgaria in the pre-accession period and in the first years after EU accession, as well as the typical affirmative stance on EU integration issues. In this sense, the slogan 'Brussels wills it!' has functioned as a key explanatory strategy.

Democratic deliberation is a phenomenon that does not predominantly depend on the legal infrastructure. If there is no censorship, information and media pluralism are guaranteed and communication rights are enshrined in the constitution and legislation, then the quality and quantity of democratic deliberation results to a great extent from the maturity of the society, the willingness of its citizens to engage in public debate and the variety and sufficiency of available information. Hence, a lack or insufficiency of democratic deliberation on EU issues in general or in Bulgaria in particular is much more a result of deficits in the social preconditions than in the legal framework. One general problem which needs a common solution is the national fragmentation of EU related deliberation and the nonexistence of a common European deliberative space.

2.12.2 The adequacy and good functioning of the constitutional review of EU matters will be evaluated differently depending on the attitude of the commentator on issues such as judicial dialogue, the legitimacy of constitutional justice as a medium between the national and supranational levels and the nature, teleology and future of the EU. A federalist approach would generally dismiss claims for more constitutional control. A moderate pro-European stance would try to reconcile and balance the need for preservation of the national institutions, interests and values enshrined in the constitutions and guaranteed by the constitutional courts with the demands of efficient and smoothly functioning EU integration. A more EU-reluctant approach would emphasise the need for sufficient time and discretion for the national institutions and in particular for the national constitutional courts to scrutinize EU measures and safeguard national sovereignty and interests.

2.12.3 The idea of suspending the application of and reviewing EU measures where important constitutional issues have been identified by a number of constitutional courts is an interesting one. Its great advantage would be that it would enhance the role of the national constitutional courts as direct guarantors of the national constitutional identity but also as the providers of indirect safeguards for developing EU integration in a way that would ensure respect for the key constitutional principles and values that fall within the scope of the common European constitutional traditions. The introduction of such a system might enhance the legality, legitimacy and efficiency of EU measures. 
On the other hand, it might additionally increase the complexity of the EU decision-making schemes and thus might contribute to the structural and functional gridlock of the EU. Moreover, the rather modest and unsatisfactory results of the system for control of subsidiarity and proportionality by the national parliaments might to some extent be reproduced also in the context of constitutional control. Of course, here one has to take into account the institutional, functional, substantial and motivational differences between the two types of control performed by the national parliaments and the national constitutional courts. One can suppose that these differences would work in favour of control by the national constitutional courts because they are better equipped and prepared for such activity in comparison to the parliaments.

\subsection{Experts' Analysis on the Protection of Constitutional Rights in EU Law}

2.13.1-2.13.2 It is very difficult to give a general assessment of whether EU integration has diminished or increased the protection of human rights. This is so because the influence of EU integration varies according to the different societal domains and the human rights that are supposed to serve as an instrument for the protection of specific interests and values. However, the objectives of EU integration should not serve as an excuse for an actual or potential reduction of the level of protection of human rights. A reduction is legitimate, as also pointed out in the Bulgarian Constitution, only in a state of war or a state of emergency and even then not all rights may be affected and the reduction should be accomplished in a proportionate manner. It is obvious that EU integration does not constitute such an extraordinary situation.

EU integration has produced certain negative effects on key constitutional principles such as the rule of law, democracy and the separation of powers. Some of them are side-effects that have emerged in the course of the establishment of the new constitutional infrastructure in Europe, others might and actually must be prevented, whereas a third group of negative factors stem from processes which are much deeper and broader than EU integration, such as globalisation, constitutional pluralism, disintegration of the nation state and the dismantling of cornerstone constitutional ideologies that were established in the earlier phases of the development of constitutional civilization.

Hence, reduction of the standard of human rights protection and infringements of the rule of law are in principle neither inevitable, nor should they be tolerated, even if they are legitimised by virtue of higher integration goals. The use of EU integration and its possible positive effects as an excuse for limiting the scope of people's freedom might result in a neopaternalistic European Leviathan.

The reduction of the standard of human rights protection is a result of different factors. These are the establishment of new arenas for policy-making which are 
difficult to subject to democratic control by the citizens and society through classical devices; the emergence of new areas of social activity and legal regulation which people are still not accustomed to; the focus on human rights infringements by states and the lack of sufficient attention to human rights infringements by international and supranational organisations such as the EU, and the durable Euro-optimism in the new EU member countries, in many of which people still believe that the EU is much more democratic and better based on the rule of law than are their own states.

The EU accession to the ECHR is a possible solution that could serve as a guarantee against human rights infringements by the EU institutions. However, there is the intrinsic danger of the emergence of contradicting practices by the European Court of Human Rights and the CJEU. If there emerges a significant disparity between the jurisprudence of these two courts and a divergent practice of the national constitutional courts, we will be confronted with an increasing pluralism of human rights standards that could be very difficult to co-ordinate. In addition, after a certain point of no return, the idea of judicial dialogue could also no longer contribute to the reconstruction of a consistent and sufficiently comprehensible and clear system of human rights.

The creation of a distinct European Constitutional Court in parallel to the already existing EU court system might create similar problems - divergent practice, differing standards for human rights protection, issues relating to legal certainty and equal treatment, etc. On the other hand, it may enhance the level of protection of human rights due to the development of a pro-human rights institutional ethos, logic and, over time, institutional memory. Moreover, it might serve as a check on and competitor of the CJEU.

The enhancement of the role of the national constitutional courts with regards to human rights protection cannot be a durable solution. It could produce divergences in practice and could tend to bring concerns stemming from the more or less specific context of a specific Member State's jurisdiction to the forefront. Thus, an institutional design with a reinforced national constitutional court would be recommendable from the viewpoint of protecting the human rights standards that have already been achieved and of compensating for loss of sovereignty, but would lead to the establishment of peaks and valleys in the geography of human rights protection in the EU. The stimulation of a proactive role for other national institutions, such as national parliaments and ombudsmen, in highlighting constitutional issues in European governance might be useful but cannot serve as a sufficient remedy for the diminishing level of human rights protection.

The achievement of a revised approach and enhanced responsiveness by the EU Courts would be a very recommendable way to proceed. It would not lead to an overburdening of the institutional scheme with an abundance of players in the field of human rights protection, would serve as a precondition for the establishment of co-ordinated and consistent practice and would be based on an already existing institution. Hence, the development of the CJEU as a constitutional court of the EU would be a positive trend. 
2.13.3 No significant issues of constitutional importance have been raised by the Bulgarian courts in their preliminary ruling requests to the CJEU. The proposals for the usage of comparative method and for enhanced examination of the national constitutional traditions of the EU Member States by the CJEU are reasonable because they may lead to a more sincere development of a shared realm of European constitutional traditions in the field of human rights. Making the arguments of the parties and of the intervening governments fully available on the Court's website might not only increase the transparency of the constitutional courts' decision-making but might enrich the scope of legal argumentation and provide inspiration for arguments in future cases.

\section{Constitutional Issues in Global Governance}

\subsection{Constitutional Rules on International Organisations and the Ratification of Treaties}

3.1.1-3.1.3 The Constitution provides for two ways to introduce international treaties into the Bulgarian legal order. The most important treaties must be ratified by the National Assembly, whereas less important ones (in the opinion of the constitutional legislator) have to be introduced by approval of the Council of Ministers by a decision.

The first group of international treaties are exhaustively enumerated in Art. 85 of the Constitution, according to which the National Assembly shall ratify and denounce the following treaties: treaties with political or military character; treaties concerning Bulgaria's participation in international organisations; treaties concerning amendment of the state boundary; treaties providing financial obligations for the state; treaties that provide for the participation of the state in international arbitrage or international judicial dispute resolution; treaties concerning human rights; treaties concerning legislative measures and treaties that explicitly require ratification. Other treaties that do not fall into the scope of Art. 85 do not need parliamentary ratification and may be implemented by a governmental decree. It was seen above that in 2005, a new type of treaty was included in the list of treaties with compulsory ratification. These are treaties that transfer competences which stem from the 1991 Constitution to the EU.

The Constitution stipulates that treaties that are ratified by the National Assembly can be amended or denounced only through the procedure provided by the treaties themselves or in accordance with the generally recognised norms of international law. This constitutional provision is a safeguard for the principle pacta sunt servanda.

An additional guarantee for the same principle is the constitutional provision that treaties that contravene the Constitution and thus require its amendment can only be concluded after the completion of such amendment. The systematic interpretation 
of this provision in combination with the provision on the absolute supremacy of the Constitution, the primacy of treaties and the generally recognised norms and principles of international law over all sub-constitutional domestic legislation and the lack of any explicit provision regarding the relationship between the EU and domestic Bulgarian law, leads to the conclusion that the Constitution implicitly subsumes EU law under the category of international treaty or general principle of international law. This stance is the result not so much of a strategy to preserve national sovereignty but of the political and practical difficulty of summoning the Grand National Assembly, which is the only body that can reorganise the hierarchy of the sources of law with regard to the supremacy of the Constitution and the primacy of international treaties.

The EU is the only supranational organisation that is explicitly mentioned in the Constitution. The UN, Council of Europe, NATO, WTO and International Criminal Court are not explicitly mentioned. However there are constitutional provisions that have implicit relevance for the participation of Bulgaria in these forms of supranational and global governance. According to Art. 24 of the Constitution, the external policy of the Republic of Bulgaria should be based on the principles and norms of international law. This article, in combination with the primacy of treaties and the generally recognised principles of international law over all Bulgarian legislation except the Constitution, creates the legal foundation both for the participation of the state in international relations and for the strong influence of the international legal order in Bulgaria.

The 2005 constitutional amendment of Art. 25 para. 4 of the Constitution allowing for the extradition of Bulgarian citizens to other states and to international courts for the purpose of criminal prosecution on the basis of an international treaty that has been ratified, published and has entered into force for Bulgaria opens the way for the application of the European arrest warrant and for the recognition of the jurisdiction of the International Criminal Court in The Hague.

Article 24 para. 2 of the Constitution imposes several objectives that have to be pursued and taken into account in the course of pursuing the external policy of Bulgaria. According to this constitutional provision, 'the foreign policy of the Republic of Bulgaria shall have as its highest objective the national security and independence of the country, the well-being and the fundamental rights and freedoms of the Bulgarian citizens, and the promotion of a just international order'.

The Preamble of the Constitution contains the constitutional values that have to be upheld by public authorities. These values are: freedom, peace, humanism, equality, justice, tolerance, human rights, human dignity and security as well as the national and state unity of Bulgaria. Hence, these values might be interpreted as implicit limitations to the participation of the state in supranational and international policy-making and to the transfer of competences to supranational or international organisations.

However, there are no explicit substantial limits to the transfer of competences to supranational or international organisations. This is due to the fact that there are no unamendable clauses in the Bulgarian Constitution as well as no specific provisions regarding the eventual scope of the competences that might be transferred to 
supranational and international organisations. There are only procedural requirements, i.e. qualified majorities, parliamentary ratification or convention of the Grand National Assembly, that have to be fulfilled.

The Bulgarian Constitution was adopted after the fall of the communist regime in Bulgaria. The main objective of the constitutional legislator was to open the Bulgarian constitutional statehood to the international legal order without undermining state sovereignty. In order to achieve this balance, the Constitution provides, on the one hand, for a monistic system for the introduction of international treaties into the Bulgarian legal system, gives priority and direct effect to international treaties that have been ratified by Bulgaria, published and have entered into force over Bulgarian legislation, apart from the Constitution, and proclaims the desire of Bulgaria to participate in the development of a just legal order. Moreover, in the course of preparing for EU accession, the Bulgarian Constitution was amended so as to allow for the integration of Bulgaria in this supranational constitutional community.

On the other hand, the Constitution seeks to preserve the control of the National Assembly over the vertical transfer of power towards supranational and international organisations in its capacity as the presumed guarantor of the people's sovereignty and state sovereignty.

3.1.4 Comments on the role of the Constitution were provided above in Sect. 1.5.3.

\subsection{The Position of International Law in National Law}

3.2.1-3.2.2 It has already been explained that according to Art. 5 para. 4 of the Bulgarian Constitution, international treaties that have been ratified pursuant to the Constitution, published and have entered into force for the Republic of Bulgaria are part of internal Bulgarian law. The ratification act is a formal one. It does not have its own normative content because its only purpose is to introduce the international treaty. Thus, the ratification act is just a device for investing international treaties with internal legal validity. Hence, the international treaty itself has direct normative force and is directly applicable. It has direct effect and prevails over contravening sub-constitutional provisions of Bulgarian law. This is due to the fact that the Bulgarian Constitution provides for a monist system for the introduction of international treaties into the national legal order.

The idea of the constitutional legislator was that the Constitution should prevail over international treaties because it is the core of crystallisation of national sovereignty. However, no institution of the constituted powers - neither the Parliament, nor the Government, the judiciary, the President, etc. - can violate the international obligations of Bulgaria because their acts will automatically be invalid due to the primacy of international treaties over the legal acts they adopt. 


\subsection{Democratic Control}

3.3.1 The National Assembly is involved in the decision-making process concerning international treaties or international issues which are of crucial importance. The Parliament declares war and peace, gives permission for the sending and use of Bulgarian military troops abroad, for the stay and transit of foreign military troops on and through Bulgarian territory and approves the conclusion of state loan treaties. War can also be declared by the President if the Parliament is not in session and there is military aggression against the territory of the state or an urgent need to fulfil international military obligations. According to Decision No. 1 of 2003 of the Constitutional Court, if the National Assembly has given a general permission through ratification of an international treaty for the deployment and use of Bulgarian military troops abroad and for the stay and transit of foreign military troops on and through Bulgarian territory, the concrete subsequent orders for deployment of the military forces can be given by the Council of Ministers.

Apart from these key instances which concern military and financial matters, the National Assembly has no concrete competences for preliminary involvement in international policy making. The main actors in the negotiation and conclusion of international treaties are the Council of Ministers, the President, the Prime Minister, the foreign minister and, on some occasions, also other senior officials within the executive.

The National Assembly can always use the general instruments for parliamentary control in order to put pressure on the Government's external policy or to obtain information from the Council of Ministers for the participation of Bulgaria in the EU or international policy making. The Constitution does not permit the execution of secret international policy by the institutions of the executive power. Extensive parliamentary debates on governmental EU or foreign policy are not very frequent. They usually concern issues that are allocated high on the agenda of the political parties, i.e. the conclusion of international treaties with financial and strategic economic implications such as state loan and energy treaties. However, in principle, external policy making, including the initiation, preparation and conclusion of international treaties as well as their implementation, is dominated by the executive power institutions in general and the Government in particular.

This situation has been reinforced by the EU membership of Bulgaria, although this is not a Bulgarian peculiarity but rather a tendency that can generally be observed in all EU Member States. The participation of the National Assembly in EU policy making and its information and control competences relating to the Government as well as the international treaties that need parliamentary ratification for entry into force have already been discussed.

3.3.2 The accession or withdrawal from an international organisation or the ratification or denouncement of an international treaty has never been the subject of a referendum in Bulgarian history. Hence it is a tradition in Bulgaria that issues concerning the participation of the state in international relations are decided by the state institutions and not by the people, even if they concern crucial moments in the 
nation's destiny. The Constitution does not provide for referendums or popular initiatives concerning international issues, but also does not prohibit them. However, it has already been explained that the Direct Participation of the Citizens in State Power and Local Self Government Act allows for referendums for ratification but prohibits referendums on denouncement of an international treaty. It has to be taken into account that these are facultative and not compulsory referendums, which may be either imperative or consultative. ${ }^{33}$

The intent of the legislator has not been to put the Bulgarian authorities in an embarrassing position by potentially having to withdraw from an international treaty or having to leave an international or supranational organisation. However, whether it is legitimate to allow Bulgarian citizens to directly decide the issue of joining international or supranational organisations but to prohibit the direct democratic decision of the issue of ending membership in such organisation is very doubtful from the point of view of the constitutional principle of democracy. This legislative decision is one-sided and does not take either representative or direct democracy seriously. It seeks to reconcile the logic that professional politicians and people's representatives can take more rational decisions when it comes to international and supranational politics with the logic that the sovereign people must have the chance to determine their own destiny, no matter what the result would be. The Direct Participation of the Citizens in State Power and Local Self Government Act would appear to presume, with a degree of paradox, that Bulgarian citizens are sufficiently mature to decide whether they want to ratify a treaty, but are less so with regard to possible dissatisfaction with that treaty leading to its denouncement. This situation becomes even more problematic from a democratic point of view if one takes into account the fact that no referendum has been held for either the NATO or EU membership of Bulgaria.

\subsection{Judicial Review}

3.4.1 International treaties are positioned above all domestic normative acts except the Constitution and the interpretative decisions of the Constitutional Court. The same is the situation with the case law of the European Court of Human Rights in Strasbourg. Hence, doubt regarding the application of an international treaty in a judicial or administrative process may only arise where there is doubt concerning its constitutionality. The 1991 Constitution provides for a preliminary control by the Constitutional Court of the constitutionality of international treaties before their ratification.

However, this control is not compulsory but facultative because it can be performed only following the initiative of one-fifth of the MPs, the President, the Council of Ministers, the State Prosecutor General, the Supreme Court of Cassation

${ }^{33}$ Belov 2009, pp. 422-507. 
or the Supreme Administrative Court. If these institutions do not make use of their competence to request a review of the constitutionality of an international treaty by the Constitutional Court, then according to Decision No. 9 of 1999, they may initiate ex post constitutional review. However, some authors stipulate that ex post control by the Constitutional Court can be carried out only on the constitutionality of the ratification procedure, but not on the content of the international treaty itself. ${ }^{34}$ The problem is that the Act of Parliament adopted for ratification of an international treaty is a formal act and does not reproduce the text of the treaty. Consequently, according to this logic, there is no other way to stop the application of an unconstitutional international treaty but to denounce the treaty through the same procedure that has been used for its introduction into the Bulgarian system, although this is unlikely to happen in reality.

The pacta sunt servanda principle creates predictability in international relations. Thus, it is a guarantee for something resembling interstate rule of law which preserves the legitimate expectations of the states and their citizens. Hence, indirectly, the pacta sunt servanda principle is also a guarantee for the internal rule of law, especially if the international treaty concerns human rights as well as measures that have a more eminent impact on human welfare and behaviour. The importance of the pacta sunt servanda principle is increasing in the context of global governance at the beginning of the XXI century. No international or supranational co-operation is possible without it.

The activity of both the international and supranational courts and of the domestic courts could sometimes put the pacta sunt servanda principle into question. The practice of the courts may transform it from a rigid and clear obligation to observe international law into a vague and framework duty of general compliance with broad initial standards. On the one hand, the virtual amendment of the treaties by the supranational and international courts might profoundly change their initial scope and the meaning of their provisions in a way that cannot be predicted in advance. Moreover, the judicial 'mastering of the meaning' of treaty provisions may have a curving path or zig-zag trajectory and thus may lead to far-reaching shifts in the obligations the states initially intended to take. On the other hand, the national courts may take decisions for the non-application of international treaties in the national legal order of the respective state, i.e. due to their contradiction with the Constitution. Thus, the biased jurisprudence of the supranational, international and national courts may in the end produce 'judicial battles' and even 'judicial wars'. These would barely be reconcilable with the principle of representative democracy and detrimental to the observance of pacta sunt servanda, legal certainty and thus, ultimately, the rule of law principles.

The jurisprudence of the European Court of Human Rights in Strasbourg and of the CJEU, based on explicit judicial activism, allow for the virtual amendment of the treaties that these courts interpret and safeguard. The initial duties that the Member States of the Council of Europe and of the EU have undertaken have been

34 Tashev 2004, pp. 64-65. 
transformed and further developed by these two supranational courts. Notwithstanding the many positive effects of their case law, the activist jurisprudence of the ECHR and especially of the CJEU may lead to the undermining of the principle that international treaties have to be concluded, ratified and amended by democratically elected institutions, the national parliaments and governments.

The non-application of international treaties by the national courts can also put the pacta sunt servanda principle in danger. Key decisions of the supreme and constitutional courts that proclaim the unconstitutionality of international legal standards or that declare that such standards endanger core constitutional and national values, are manifestations of national sovereignty. Hence the judicial dialogue that could possibly emerge out of a 'case law ping-pong' played by the supreme national, international and supranational jurisdictions is actually an expression of a fight for sovereignty. It serves to delimit the seemingly flexible but in fact still very important boundaries between the history and the future of the national and supranational political communities and the core and periphery of the constitutional consensus. Such dialogue raises concerns from the viewpoint of democracy, but is usually legitimised by arguments based in constitutional politics.

The non-observance of the pacta sunt servanda principle due to the non-application of provisions of international treaties by the ordinary courts would be problematic in several aspects. It would undermine the capacity of the political institutions of representative democracy - the parliaments and the governments - to dispose of the realm of discretion needed for the accomplishment of their tasks in international relations. Moreover, such judicial practice may be manifested in a diffuse, polycentric and creeping form, undermining legal certainty, the principle of legitimate expectations and the international obligations of states.

On the other hand, the protection of core constitutional values and principles by both the national courts and the international and supranational courts may serve as an important guarantee for the ethical, social and political integrity of the communities for whom the relevant courts are presumed to speak, and may represent a safeguard for human liberty and human rights. At a time when the legitimate channels for democratic representation are malfunctioning, countermajoritarian institutions such as the courts may play an important and even crucial role in the preservation and development of the constitutional consensus, the constitutional identity and personal prosperity. In such case, however, the rule of law will prevail over the separation of powers and democracy.

\subsection{The Social Welfare Dimension of the Constitution}

3.5.1-3.5.2 The issues raised by these questions are not directly relevant for Bulgaria. 


\subsection{Constitutional Rights and Values in Selected Areas of Global Governance}

3.6.1 The issues raised by these questions are not directly relevant for Bulgaria.

\section{References}

Belov M. (2009) Пряка демокрация - национални и сравнителноправни аспекти (Direct democracy - National and comparative aspects). Sibi, Sofia.

Belov M. (2010) Същност и типология на конституционния консенсус. В: Киров, Пл. (съст.) Национални и европейски измерения на съвременния конституционализъм (Concept and typology of the constitutional consensus). In: Kirov P. (ed.) National and European dimensions of the contemporary constitutionalism. St. Kliment Ohridski University Press, Sofia, pp. 188224.

Belov M. (2012) Източниците на правото в действие - правосьдието между позитивизма и реализма (The sources of law in action - the judiciary between legal positivism and legal realism). Savremenno Pravo 4:29-45.

Bogdanor V. (1988) Constitutions in the Democratic Politics. Gower, London.

Drumeva E. (2009) Primacy of the EU Law in the National Constitutional Space - Reflections. In: Pernice I., Tanchev E. (eds.) Ceci n'est pas une Constitution - Constitutionalisation without a Constitution? Nomos, Baden-Baden, pp. 101-102.

Grimm D. (2010) The Achievement of Constitutionalism and its Prospects in a Changed World. In: Dobner P., Loughlin, M. (eds.) The Twilight of Constitutionalism? Oxford University Press, Oxford, pp. 4 et seq.

Jellinek G. (1905) System der subjektiven öffentlichen Rechte. Mohr, Tübingen.

Kiiver P. (2006) The National Parliaments in the European Union. Kluwer, The Hague.

Klein E. (1983) The Concept of the Basic Law. In: Starck C. (ed.) Main Principles of the West German Basic Law. Nomos, Baden-Baden, pp. 21-22.

Kornezov A. (2012) Bulgaria. In: Laffranque J. (ed.) The Protection of Fundamental Rights Post-Lisbon, Reports of the XXV FIDE Congress Tallinn 2012, Vol. 1. Tartu University Press, Tallinn, pp. 259-283.

MacCormick N. (1993) Beyond the Sovereign State. MLR 56(1):16 et seq.

Modeva, М (1997) Таблици. В: Конституционен съд. Юриспруденция (1991-1996) (Tables. In: Constitutional Court. Jurisprudence (1991-1996)). Open Society Institute, Sofia.

Modeva, М. (2010) Таблици. В: Конституционен съд. Юриспруденция (1997-2006) (Tables. In: Constitutional Court. Jurisprudence (1997-2006)). Open Society Institute, Sofia.

O’Brennan J., Raunio T. (2007) National Parliaments within the enlarged European Union. From 'Victims' of Integration to Competitive Actors? Routledge, Abingdon.

Panova P., Kashumov A. (2012) Bulgaria. In: Laffranque J. (ed.) The Area of Freedom Security and Justice, Including Information Society Issues, Reports of the XXV FIDE Congress Tallinn 2012, Vol. 3. Tartu University Press, Tallinn, pp. 213-220.

Peters A. (2005) Global Constitutionalism Revisited. International Legal Theory 11:41 et seq.

Peters A. (2006) Compensatory Constitutionalism: The Function and Potential of Fundamental International Norms and Structures. LJIL 19:580 et seq.

Sartori G. (1994) Comparative Constitutional Engineering: An Inquiry into Structures, Incentives and Outcomes. Macmillan Press, Houndimils.

Tanchev E. (2014) The Primacy or Supremacy of International and EU Law in the Context of Contemporary Constitutional Pluralism. In: Birmontiene, T. (ed.) Modern Tendencies of 
Constitutional Justice: the Relation Between National and International Law. Constitutional Court of the Republic of Lithuania, Vilnius, pp. 69-75.

Tanchev Е. (2003) Въведение в конституционното право (Introduction to constitutional law). Sibi, Sofia.

Tanchev E., Belov M. (2008) Constitutional Gradualism: Adapting to EU Membership and Improving the Judiciary in the Bulgarian Constitution. EPL 1(1): 3 et seq.

Tashev R. (2004) Обща теория на правото (General theory of law). Sibi, Sofia.

Tsebelis G. (1990) Nested Games: Rational Choice in Comparative Politics. University of California Press, Berkley.

Vazak K. (1984) Pour une troisième génération des droits de l’homme. In: Swinarski C. (ed.) Etudes et essais sur le droit international et sur le principes de la Croix-Rouge en l'honneur Jean Pictet. Kluwer, The Hague, pp. 837-850.

Open Access This chapter is licensed under the terms of the Creative Commons Attribution 4.0 International License (http://creativecommons.org/licenses/by/4.0/), which permits use, sharing, adaptation, distribution and reproduction in any medium or format, as long as you give appropriate credit to the original author(s) and the source, provide a link to the Creative Commons license and indicate if changes were made.

The images or other third party material in this chapter are included in the chapter's Creative Commons license, unless indicated otherwise in a credit line to the material. If material is not included in the chapter's Creative Commons license and your intended use is not permitted by statutory regulation or exceeds the permitted use, you will need to obtain permission directly from the copyright holder.

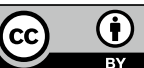

